\title{
How does Uncertainty Resolution Effect VC Syndication?
}

\author{
Z. Ayca Altintig* \\ Chapman University \\ altintig@chapman.edu \\ Hsin-Hui Chiu \\ California State University, Northridge \\ hsinhui.chiu@csun.edu \\ M. Sinan Goktan \\ California State University, East Bay \\ sinan.goktan@csueastbay.edu
}

Current Draft: July 10, 2011

Keywords: 510(k), venture capital, syndication, certification, IPO

JEL Codes: G24, G32

\footnotetext{
${ }^{*}$ Z. Ayca Altintig is an Assistant Professors of Finance at the Argyros School of Business and Economics, Chapman University, One University Drive, Orange, CA 92866. Hsin-Hui Chiu is an Assistant Professor of Finance at the College of Business and Economics at California State University Northridge, 18111 Nordhoff Street, Northridge, CA 91330. Sinan Goktan is an Assistant Professor of Finance at the College of Business and Economics at California State University East Bay, 25800 Carlos Bee Blvd, Hayward, CA 94542.
} 


\begin{abstract}
:
All medical device companies require FDA 510(K) clearance before they can market their products. Using this external certification as a natural experiment, this paper analyzes the dynamics of the syndicate formation process of venture capital firms as well as the certification role that venture capitalists may play. Our results suggest that FDA $510(\mathrm{k})$ clearance does serve as an outside certification reducing uncertainty that leads to a larger amount of capital flow into the company from a greater number of investors after the approval. Pre-approval syndicate formation seems to be driven by a search for second-opinion with greater likelihood of IPO exit, while post-approval syndicate formation seems to be driven by the need for capital on lower risk investments that also have lower chance of an IPO exit. We test several non-mutually exclusive hypotheses on project selection, second opinion, and diversification and find support for our hypotheses. Younger VC firms are more likely to invest in start-ups pre-certification and start-up companies that can secure funds pre-certification are more likely to make it to IPO.
\end{abstract}




\section{Introduction}

Entrepreneurial companies have high growth potentials, but at the same time suffer from high uncertainty and high information gathering costs. Venture capital (VC) firms provide much needed capital as well as business and managerial expertise to these early-stage, generally high risk and high-tech entrepreneurial companies (Lerner 1995). VC funding usually provides for staged financing and active VC involvement in the governance of the entrepreneurial company ${ }^{1}$. Therefore VC firms serve a monitoring and certification role in alleviating the information asymmetry problems faced by their investments and increase the chances of successful exit through initial public offerings (IPOs) or acquisitions (Megginson and Weiss 1991, Barry, Muscarella, Peavy and Vetsuypens 1990).

VC financing is often syndicated. Tian (2011) notes that about $70 \%$ of the VC investments between 1980 and 2005 were through syndicates and approximately 88\% VC- backed initial public offerings (IPOs) during the same period were backed by two or more VC firms. There is considerable research trying to determine the rationale behind syndicate formation as well as the dynamics within a VC syndicate. There are several explanations of VC investment decisions and syndicate formation. We test three nonmutually exclusive hypotheses in this paper. "Project selection” hypothesis argues that VC firms are skilled at screening highly profitable investments at an early stage which gives them the opportunity to get high returns on their high-risk investments. The “second opinion” hypothesis argues that syndication is a method for the VC firms to obtain another credible opinion about the value of the entrepreneurial project (Casamatta

\footnotetext{
${ }^{1}$ All through the paper "firm” refers to venture capital firms and “company” refers to the entrepreneurial companies venture capitalists invest in.
} 
and Haritchabalet 2007 and Cestone, Lerner, and White 2006). The “diversification hypothesis” argues that syndication is a means for VC firms to reduce risk through standard diversification and undertake large investments that may be otherwise impossible (Lockett and Wright 1999, 2001).

We use the FDA 510(k) premarket approval process for medical devices as a natural experiment to test these hypotheses and examine the formation and dynamics of VC syndicates. Biotechnology and Healthcare is the second biggest sector in the VC industry following the Internet and Computers industry. The industry covers roughly $17 \%$ of all companies receiving VC investments. All medical device companies within this industry have to get FDA pre-market approval before they can market any medical device in the United States. FDA has only approved around 78\% of all 510(k) applications during 2003-2007 period and this percentage has declined to around 53\% in the 2007-2009 period. $^{2}$ However, due to data limitations, we only have access to companies that receive 510(k) clearance but not to those do not. Therefore, our entire data set is built on the group that successfully receives clearance.

Before FDA 510(k) clearance, the informational asymmetry between the medical device company and investors is very high. Government clearance for marketing can serve as a source of external quality certification which reduces some of the uncertainty about the future expected success (and cash flows) of the entrepreneurial venture. Since only high quality medical device investments will be able to secure FDA 510(k) approval, ability to screen these investments early on and select them into their investment portfolios will set VC firms apart. We expect that the highest return on investment for

\footnotetext{
${ }^{2}$ This information has been obtained from the United States Government Accountability Office (USGAO) January 2009 Report to Congressional Addressees.
} 
the VC firms would be obtained if they can spot the promising and potentially successful medical device companies early on and secure the entire venture financing before the FDA approval. We hypothesize that companies that are able to secure VC funding only after 510(k) approval are less profitable companies that were able to attract financing only after some of the uncertainty about their product has been resolved. Finally, companies that secure funding before approval and acquire 510(k) approval during the funding process would fall into the category in between the two extreme cases that we define above. Using this natural experiment gives us the opportunity to test some of the well-known hypotheses about the role of VCs in reducing information asymmetry, syndicate formation and exit strategies.

According to the "project selection” hypothesis, we expect VC firms to have the ability to screen high return investments early on even when the product is not yet ready for marketing. Thus, on average, we expect the companies that manage to get all of their VC financing before the FDA 510(k) approval, when information asymmetries are highest, to be the most promising and potentially successful ventures, and therefore more likely to eventually make it to IPO. Better companies should have already been identified and invested in early on, before reaching the 510(k) approval stage. Following the "second opinion" hypothesis, we expect the VC firms that seek "second-opinion" before any external certification and more likely to be younger VC firms who need “second-opinion” the most. Finally, with “diversification” hypothesis we argue that VC firms are more likely to form syndicates (rather than being the single investor) to finance companies after 510(k) approval to diversify their risks. Once informational asymmetry problems have been alleviated by the FDA 510(k) process, it is relatively safer for VC 
firms to invest in medical device ventures. If a syndicate is formed only after the FDA approval or if new VC firms are invited to the syndicate after FDA approval, we expect these companies to be less profitable and less likely to eventually make it to IPO since these companies did not attract VC funding prior to external certification.

We use a dataset of 974 venture-backed companies in the medical device industry and 2,033 venture capital firms that invest in these enterprises in a total of 9,942 rounds of investment during 1980 - 2007 to test our hypotheses. Our contribution is two-fold: We use this unique natural experiment to test the standard theories of VC certification and syndication while looking in detail into the dynamics of the VC syndication process.

Our results indicate that uncertainty resolution by the FDA 510(k) process leads more VC firms to participate in the financing round following the certification. Moreover, venture-backed companies are able to secure more dollar value in investment post 510(k) certification. These results suggest that FDA 510(k) clearance does indeed reduce uncertainty and lead to greater VC fund flows to medical device ventures. Yet, this increase in flow of funds is not translated into higher post-round valuations for venture-backed companies.

Consistent with our expectations, venture-backed medical device companies that secure all of their funding before the 510(k) process tend to be younger, receive significantly fewer investment dollars and are less likely to be backed by a single lead VC firm but are more likely to make it to IPO. These results are mostly consistent with our hypotheses on "project selection" and "second opinion". These VC investments tend to be higher risk investments with higher returns. These VC firms are able to identify promising projects without external certification. At the same time, they seem to utilize 
the second opinion provided by the syndicate before receiving external clearance. VC firms that invest in companies, which receive all funding before 510(k) approval tend to be more experienced VCs, suggesting project selection skills by these firms. Since these are more experienced VCs, they also tend to be in less need of second opinion by external certification. On the other hand, younger lead VC may in more need for second opinion when information asymmetry is high. We find younger VCs tend to go for ventures, which have already received 510(k) approval and use it as a second opinion on the value of the venture.

We find that venture-backed medical device companies that secure all of their funding only after the $510(\mathrm{k})$ process tend to be older companies that receive less number of rounds from a smaller number of investors and are less likely to eventually make it to IPO. For this group, age of lead VC is positively associated with number of investors in company. These results further confirm our hypothesis on diversification. At this stage, ventures tend to be less risky investments due to $510(\mathrm{k})$ clearance but with lower likelihood of an IPO exit. Relatively more experienced lead VCs invite more investors so that they do not have to carry out the investment entirely on their own. This suggests that VC firms at this stage syndicate for diversification purposes.

Section 2 describes the details of the FDA 510(K) clearance process, prior literature on the topic and hypothesis development. Section 3 presents the data and section 4 discusses empirical results. Lastly we conclude in section 5. 


\section{Background and Prior Research}

\subsection{FDA 510(k) Process}

According to the FDA website, Food, Drug and Cosmetics Act requires medical device manufacturers to notify the FDA of their intent to market a medical device at least 90 days in advance. This is known as Premarket Notification - also called PMN or 510(k). This allows the FDA to determine whether the device is "equivalent" to a device that has already been approved so that the new product can receive $510(\mathrm{k})$ approval based on its equivalency to an existing device or procedure. If the device is "unique" and is not necessarily equivalent to an existing device then FDA requires a more thorough investigation to determine if the device qualifies for $510(\mathrm{k})$ clearance.

Specifically, medical device manufacturers are required to submit a premarket notification if they intend to introduce a device into commercial distribution for the first time or reintroduce a device that will be significantly changed or modified to the extent that its safety or effectiveness could be affected. Before marketing a device, each submitter must receive an order, in the form of a letter, from FDA which finds the device to be substantially equivalent (SE) and states that the device can be marketed in the U.S. This order "clears" the device for commercial distribution. The submitter may market the device immediately after $510(\mathrm{k})$ clearance is granted.

One of the difficulties in VC studies is to identify a measure that would give an objective indication about the quality of the start-up before the exit period. Usually, the quality of the start-up can only be observed after the company is taken to the market. This prevents the analysis of the investment behavior of different VC firms during or before the investment period. The FDA 510(k) approval process provides us with an 
external signal that certifies the quality of an entrepreneurial venture before the VC firm exit. Thus, we use it as a natural experiment that reduces the uncertainty of VC investments and allows us to test several VC syndication and certification theories.

\subsection{Prior Research and Hypothesis Development}

There is substantial information asymmetry between start-up firms and private investors with capital (Admati and Pfleiferer 1994). A third-party intermediary such as the VC firm helps the start-up companies convey private information to potential investors (Megginson and Weiss 1991; Hsu 2004), and at the same time screens through projects and signals on behalf of capital providers. Through the investment and certification of venture capitalists, private companies may enhance profitability and gain access to equity markets easily and eventually go public.

Gompers (1995) relates the staged nature of VC investments to agency and monitoring costs between the venture-backed company and the VC firm. Venture capitalists usually concentrate investments in early state and high technology companies where information asymmetries are the highest. These are high risk investments with high expected returns. Staging of capital infusions allows venture capitalists to gather information and monitor the progress of firms, maintaining the option to periodically abandon projects. The duration of funding and hence the intensity of monitoring should be negatively related to expected agency costs. Other than the VC firms involved with the company, a third party such as the FDA which is a government agency, can also help resolve the information asymmetry problem by sending a credible signal to the market.

We use the FDA 510(k) approval as a natural experiment to relate VCs' syndicate formation needs and eventual successful exits. Since all medical device companies need 
FDA 510(k) approval to be able to market and sell their products, and since FDA does not approve all applications, 510(k) approval serves as an outside certification of VC investment quality. This way it reduces the information asymmetry between the start-up company and its VC investors. If the FDA 510(k) clearance serves to reduce uncertainty and information asymmetry, we expect to see an increase in the number of VC firms participating in investments in the rounds following the FDA approval. Also, we expect to see that companies can secure more dollars in investments and have higher valuations after external certification through 510(k) approval.

\section{H1.1: More VC firms are expected to participate in the financing of start-up firms after 510(k) approval. \\ H1.2: Start-up companies should secure more investment dollars and have higher valuations post $510(\mathrm{k})$ approval.}

Skilled VCs might choose high quality projects and earn higher rates of return through successful IPOs ${ }^{3}$. According to Brander, Amit, and Antweiler (2002), syndication based on second-opinion will occur only when it is not clear whether the project should be accepted or rejected. There will be no need for a second opinion if the venture is clearly acceptable (assessment yields a high expected value) or could be rejected outright (quality is sufficiently low). Following their argument, VC firms inviting more VCs into the syndication in later rounds would do so if the chance of successful exit is relatively low for that start-up.

\footnotetext{
${ }^{3}$ Sorensen (2007) suggests that more experienced VCs are more likely to take their investments public. Companies prefer experienced VC firms, also experienced VC firms prefer late-stage and biotechnology companies, and these agents tend to match resulting in a higher probability of IPO exit.
} 
Venture capitalists can choose to join the venture at various stages of the young start-up company. The timing of the entrance and the choice of syndication before vs. after a major FDA approval not only suggests the project selection ability of VCs but also infers the probability of future successful exits through IPO. 510(k) approval serves as an external validation for the future prospects of the startup company. Investment by VC firms prior or after this validation suggests different rationales and reasoning. We first categorize the syndication process into the following four types:

1. A start-up company receives all funding only before $510(\mathrm{k})$ approval.

2. A start-up company receives all funding only after 510(k) approval.

3. A start-up company receives funding both before and after the approval. A new VC firm is invited to join syndicate after the approval.

4. A start-up company receives funding both before and after the approval. No new VC firms are invited to join syndicate after the approval.

A promising startup company may not necessarily need to receive 510(k) clearance for its product to signal its quality to acquire more VC funding. In fact, according to "project selection" hypothesis, VC firms have the ability to screen better projects early on and invest in them at the early stage to increase their return on investment. In such a case, $510(\mathrm{k})$ approval would be a formality before commercial distribution and VC firms would more likely invest in these promising companies although they have not acquired their 510(k) certification. We would also expect no new VCs to be invited into the syndicate for such companies after the approval since the expected return from such investments would be high. 
Folklore suggests that VC exit through an IPO is the first choice among several exiting options ${ }^{4}$ (i.e. IPO, acquisition, etc.). Brander, Amit, and Antweiler (2002) and Sorensen (2007) use this measure to evaluate the success of portfolio companies. Syndicates with superior projects are more likely to take the company public. On the other hand, syndicates would be more likely to invite new participants into syndication when they are less certain about the potential of the project and are more willing to share the return/risk with new participants. Therefore, we hypothesize the following:

\section{H2.1: A start-up company which receives funding only before 510(k) approval is more likely to make it to an IPO.}

\section{H2.2: A syndicate which invites new VCs after $510(k)$ approval is less likely to make it to an IPO.}

Venture capitalists tend to form syndicates for investments. ${ }^{5}$ The most basic rationale for syndicate formation is diversification of investments in order to reduce capital constraints which we will explore more in a later hypothesis. However, prior research has also shown that other explanations seem to complement the diversification explanation for syndicate formation. VC firms might be more reluctant to be the single investor in a given company when the information asymmetry is higher. According to the "second-opinion" hypothesis, VC firms validate their opinions on a certain project

\footnotetext{
${ }^{4}$ Several studies show success of a VC firm investment is directly linked to a successful exit through an IPO. Lerner (1994b) and Cumming, Fleming, and Schwienbacher (2005) suggest that VC firms can time IPO markets and take their investments public at market peaks. Ball, Chiu and Smith (2011) examine VCbacked firms exit choice and test hypotheses that levels and relative shares of IPO and acquisitions are affected by marketing timing or pseudo market timing.

${ }^{5}$ Chemmanur and Tian (2011) develop a theoretical model to examine syndicate formation in VC financing. They hypothesize that companies with more complex projects are more likely to seek financing from a VC syndicate. Tian (2011) examines the impact and value creation of VC syndicate versus a single VC firm for entrepreneurial companies. VC syndicates invest in younger firms, in earlier rounds, and at earlier stages of the firm life cycle relative to an individual VC firm.
} 
through the process of syndication. Syndication helps to reduce information asymmetry between entrepreneurial companies and VC investors (Lerner 1994a, Gompers 1995 and Fried and Hisrich 1994). Lerner (1994a) uses a sample of 271 private biotech firms and shows that established venture capitalists tend to syndicate with VC firms of similar experience in earlier rounds and with their peers and less experienced VC investors in later rounds. His results indicate that syndication is used by lead VC firms to double check their opinion on the project against other knowledgeable sources.

Similarly, Casamatta and Haritchabalet (2007) develop a model where the level of VC experience is the major determinant of the syndication decision. Also Casamatta and Haritchbalet (2007) model suggests that syndication occurs in early-stage rounds with information gathering motives; unlike the financial constraint motive which predicts syndication as more likely in later-stage rounds.

Since information asymmetry is at its highest in the first round of investment, it is rather important to choose syndicate members at this stage from experienced VC firms. If 510(k) approval is regarded as an external certification that reduces information asymmetry, VC firms will tend to syndicate more when information uncertainty is high. On a related note, taking on the unknown venture requires the expertise and capital resources of VC firms. With a high level of information uncertainty, VC firms with little investment experience may find themselves in need of second opinions to validate their venture investments. We hypothesize the following:

\section{H.3.1: It is more likely for younger (inexperienced) VCs to invest in projects with 510(k) approvals.}

\section{H.3.2: It is more likely for older (more experienced) VCs to invest in projects without 510(k) approval.}




\section{H.3.3: It is more likely for inexperienced lead VCs to syndicate in investment rounds prior to receiving $510(\mathrm{k})$ approval.}

VCs form syndicates for various reasons and one of them could be to diversify firm portfolios. VC firms may have several investments in different start-up companies and investment strategies could range from a high concentration in small numbers of companies to a diversified strategy with small investments in large number of start-ups. It could create much financial burden on some lead VCs if they have to carry out the entire

funding on their own. VCs therefore could syndicate for diversification purposes and free up some of their own capital.

Prior to the 510(k) approval, when information asymmetry is high, it is likely for the VC firm to require a second opinion and syndicate the venture among its peer investors as hypothesized in H3.3. On the other hand, a VC firm which chooses to invest in a project after 510(k) approval may have a different motivation in mind, since the required second opinion is provided, in this case, by the external certification of the 510(k) approval. Young (inexperienced) VCs may still look for guidance on company valuation even after 510(k) clearance along with other rationales. However, more experienced VCs will be more likely to syndicate for diversification purposes after the 510(k) approval. More experienced lead VCs may invite others into an investment so that they do not have to carry the investment through entirely on their own. Doing so would allow them to complete the investment and free up some capital at the same time.

Therefore, we hypothesize the following:

\section{H4: It is more likely for more experienced lead VCs to syndicate in projects with all funding after certification.}




\section{Data and Methodology}

\subsection{Data Source and Variable Definition}

In order to be included in our sample, the company must have received its $510(\mathrm{k})$ clearance from FDA. $510(\mathrm{k})$ clearance is a necessary step to take for a medical company if they intend to introduce a device into commercial distribution for the first time or reintroduce a device that will be significantly changed or modified to the extent that its safety or effectiveness could be affected. This data is publicly available at the FDA website :(http://www.fda.gov/MedicalDevices/ProductsandMedicalProcedures/DeviceAp provalsandClearances/510kClearances/default.htm)

However, this data is only available for successful $510(\mathrm{k})$ applications. Thus, we only have data on $510(k)$ clearances that have been successfully approved. For a medical company, there might be multiple 510(k) clearance applications filed with the FDA. We specifically focus on the first 510(k) approval for a given company since this initial approval is especially important for a venture backed company. The first approval shows that the company has reached a stage where it is now ready to launch a product to be sold in the market. We use this important event as a signal of reduced uncertainty and lower information asymmetry in order to analyze the investment characteristics of VC firms around this event.

The 510(k) decision has three different classes - class I, class II and class IIIdepending on how "unique" the underlying medical device is, class III being the more complicated group of devices. We have controls in our regressions for the different classes of clearances that are reported for a given company from the FDA website. We also collect information on the submission date and the acceptance date of the 510(k) 
approval. We match our data from the FDA website with data from VentureXpert Securities Data Company (SDC) based on company names. We manually go through the list of companies in both datasets to make sure that we get the optimal matching.

We end up with a sample of 974 venture-backed companies in the medical industry from period 1980-2007. We are able to identify 2,033 VC firms that invest in these companies and the total number of rounds of investment that VC backed companies receives during this time period is 9,942. All of our companies are from the "Medical/Health/Life Science" industry class group in the SDC database since FDA $510(\mathrm{k})$ clearance is only required for companies in the medical industry.

At the company level, we obtain information on the age of company at first round, the total amount invested in company, the number of VC firms that invested in the company, the number of rounds of investment that the company received, the number of days from approval to initial funding, the time from approval to IPO, dummy variables identifying a company as eventually going to an IPO or being acquired and finally a dummy variable indicating whether the company is a buyout.

At the VC firm level, we obtain information on the age of VC firm at first investment. We identify the lead investment firm which is the firm in the syndicate that typically undertakes the main task of monitoring and consulting (Gompers 1996). We identify the lead investor following Lee and Wahal (2004) and choose the VC firm that provides the investment in the first round as the lead investor and if there is a tie with other VC firms in the amount and the timing of the first investment, we call that company as one that has multiple lead VC firms. 
For VC firm experience we use two measures: the age of the VC firm and the total investments (\$ million) made by the VC firm in prior years. We calculate the age of the VC firm by subtracting the founding year of the VC firm (from SDC) from year. We calculate the total prior VC firm investments variable for each year for each VC firm by summing the total investments of the VC firm in companies in all prior years within the SDC data. We then use the year the VC firms makes its first investment in the portfolio company as the reference year to assign the experience of the VC firm for each observation.

For each company we also create three weighted measures: weighted average VC firm age, weighted average VC firm experience and weighted firm investment diversification. Weighted average VC firm age for a given company is the age of each VC firm within its syndicate multiplied by the weight of each firm. Weight of each firm in the syndicate is computed (for all weighted variables) as the percentage of the total investment of the VC firm divided by the total dollar investment the company received. Weighted average firm experience is the weighted average of total investments made by VC firm in prior years. Weighted firm investment diversification is the percentage of investment invested to the company by a VC firm out of the total investment that the VC firm invests in that same year. We also calculate standard deviation on age of the VC firms within the syndicate and total amount a VC firm invested in the company.

At the investment round level, we obtain information on days between rounds, the number of investors each round, the total dollar investment in a given round and the reported valuation of the company after a given round. 
In order to mitigate the effect of outliers or data errors, we winsorize all variables in our models at $1 \%$ and $99 \%$ levels. We control for time and industry varying characteristics by year dummies representing the year of the first round of investment and industry dummies representing industry sub-group three as defined in VentureXpert database, respectively. We also control for the class of 510(k) approval in our analyses.

Since we use the $510(\mathrm{k})$ clearance date as our event date to examine the investment patterns, we group our companies into three main categories as seen in figure 1. The first group we name "All funding before $510(\mathrm{k})$ clearance" refers to those companies that receive all funding before any 510(k) clearance and nothing more after the approval. The second group we name "All funding after 510(k) clearance" refers to those companies that have already received $510(\mathrm{k})$ clearance before receiving their first round of VC investment. The third group " $510(\mathrm{k})$ clearance during funding" refers to companies that receive their $510(\mathrm{k})$ clearance during the VC investment period. We further divide the last group into two sub-categories in some analyses to investigate the reason VC firms are invited into the existing syndicate after 510(k) approval.

\subsection{Descriptive Statistics and Empirical Results}

This section introduces the descriptive statistics and regression results for our sample. Sub-section 1 gives descriptive statistics of the variables we use in our models. Sub-section 2 introduces the multivariate regression results.

\subsubsection{Characteristics of the venture backed companies}

Table 1, Panel A presents the descriptive statistics for the variables on the venture- backed companies in our sample. The sample characteristics are presented for 
sub-groups defined according to the status of the VC investment at the time of $510(\mathrm{k})$ certification. Three groups are as described in the prior section and explained in Figure 1 according to the time of investment.

According to our results, companies that receive all VC funding before $510(\mathrm{k})$ certification have an average age of 2.75 years at the time of the first investment. On the other hand, companies that already have 510(k) certification before they receive any VC funding have an average age of 6.79 years. Finally, group three companies that receive 510(k) funding during the investment period have an average age of 1.78 at the time of the first investment. This result is expected since by definition, companies that receive funding after 510(k) approval are expected to be older/mature companies. The average total dollar investment received by companies with all funding after $510(\mathrm{k})$ certification is $\$ 5.40$ million whereas the amount received by companies with all funding before certification is $\$ 4.45$ million. This result, combined with the evidence on the age of companies is interesting since companies that receive all funding before certification are younger and the total amount that goes into these companies is less. Companies that receive funding only after $510(\mathrm{k})$ approval seem to be able to draw more capital compared to the rest of the groups.

When we look at the number of VC firms that invest in these companies, we see that those companies which receive 510(k) certification during VC funding seem to have more VC firms involved. This group is followed by those that receive all funding before 510(k) certification. Companies that receive funding only after 510(k) certification have the least number of investors. This result is intuitive since established companies that already have 510(k) certification might need relatively less monitoring and less risk 
diversification due to the reduced information asymmetry. The evidence on the number of rounds companies receive also supports this argument. Companies that receive funding during the investment period and those that receive all funding before $510(\mathrm{k})$ certification receive more rounds of investment. This is consistent with the evidence that these companies require closer and more frequent monitoring. The number of days required from the day of initial investment to $510(\mathrm{k})$ certification is 2260 days (6.19 years) for companies that receive all funding before certification versus 862 days (2.36 years) for companies that receive during the investment period.

Table 1, Panel B shows the results for the variables related with VC firm characteristics. According to the results, 37\% of the firms in our sample are young VC firms following Gompers (1996) definition of 6 years old or younger. Percentage of young VC firms that invest only before $510(\mathrm{k})$ and only after $510(\mathrm{k})$ approval is not very different from the overall sample average. However, when we examine young lead VC firms, we see that lead VC firms are more likely to be young VCs in syndicates that invest only before $510(\mathrm{k})$ and only after 510(k) approval (22\% and 20\%, respectively) compared to those companies that receive $510(\mathrm{k})$ approval during the investment period (11\%). Young VC firms are more likely to be the lead VCs for companies that are either early in the process or those that are already established. This is consistent with previous literature where young VC firms tend to take higher risks and invest in companies even when uncertainty is really high; at the other end of the spectrum, they invest in sure investments to compensate for second opinion purposes. More experienced lead VC firms seem to take their company through the $510(\mathrm{k})$ process during the investment period themselves which is more consistent with their greater ability to supervise and 
monitor their portfolio companies. There does not seem to be a significant difference between the age of the VC firms at the initial investment stage and the amount of total investment made by VC firms among different groups.

Table 1, Panel C shows the descriptive statistics for the round level data. According to the results, number of investors in each round is highest when the company receives its $510(\mathrm{k})$ approval during the funding period. These companies seem to receive greater supervision and monitoring form their VC investors. When companies receive funding only before $510(\mathrm{k})$ certification, the number of investors in each round is again higher compared to the group of companies that receive all of their investments after the 510(k) certification. This is consistent with our expectations since companies with funding only after are expected to be in less need of supervision or VC firms do not need to diversify their risk as much for other investments. The amount of funding per round is again highest for companies that receive 510(k) certification during funding and is lowest for those that receive before $510(\mathrm{k})$ certification.

In Table 2, we list the univariate tests for some selected variables. Instead of our three sub categories that we use in Table 1, we divide the sample into two, based on whether the observation was before or after 510(k) certification. According to our results, number of days between rounds, number of investors in round and amount invested in round is significantly higher after certification. These results are consistent with our previous discussions and show that the differences in investment behavior of VC firms before and after company receives $510(\mathrm{k})$ certification are significantly different and the differences are consistent with the prior literature we discussed in Section 3. 


\subsubsection{Regression Results}

Table 3 presents the regression results at the investment round level. Our goal here is to analyze the effect of $510(\mathrm{k})$ approval with multivariate analyses. To be able to do that in this section we focus on the observations in which the company receives $510(\mathrm{k})$ approval during the investment period. We restrict our sample to these observations because we would like to capture the differences in our dependent variables in the investment rounds right before and after the approval.

In our first regression in Table 3, the dependent variable is the log of the total dollar amount of investment in a given round. Our results suggest that as the percentage change in the number of VC investors increases from the prior round, so does the amount of dollar investment. Age of the company seems to be negatively related with the dollar amount of investment. Companies that eventually make it to IPO and companies that receive greater total dollar amount of investment also seem to be receiving greater amounts of investment per round. Our variable of interest is Dummy for 510(k) approval since prior round, which takes a value of 1 if there has been an approval since the last round of investment. According to our results, controlling for other factors, VC firms tend to invest more in the round following the $510(\mathrm{k})$ approval. These findings support our hypothesis one with the positive effect that we expect as a result of the approval and consequent resolution of uncertainty.

Next we look at the percentage change in the number of investors from previous round as our dependant variable in Table 3, column 2. As the amount of VC firms in a given round increases so does the total dollar amount of investment. As the total dollar amount of investment increases the change in the number of investors in a given round 
decreases. Our variable of interest Dummy for 510(k) approval since prior round is positively related with the dependant variable. This result suggests that $510(\mathrm{k})$ certification draws more VC firms to invest in a given round and is again consistent with hypothesis one as the positive effect of certification that we expect.

In Table 3, Panel B, we look at the valuation effect that the certification might have on the venture backed company. For this analysis we can only use observations that have post round valuation numbers available in the data set. As a result, our sample size is significantly reduced to 399 and this reduces the power of our regression model. Our dependent variable is the percent change of post round valuation relative to prior round. According to our results, companies that have greater \% change of dollar investment from previous round and greater \% change in number of VC firms have greater post round valuation changes relative to the previous round. Percentage change in post round valuation is related with the percentage change in the dollar amount of investment as expected. Greater change in the number of investors is also associated with greater percentage change in company valuation. Our variable of interest Dummy for 510(k) approval since prior round is not statistically significant. In other words, company post round valuation is not necessarily higher after the certification. This does not support part of Hypothesis 1.2, since we would expect certification to increase post round valuation. This result might be due to the low power of our model stemming from fewer numbers of observations. It might also be due to the correlation that our variable might have with other variables in the regression. From previous models we show that certification causes more funds to flow into the company and more VC firms participate in the round following certification. These two factors are loading as significant factors in the 
valuation model as well. Thus, our variable Dummy for 510(k) approval since prior round is likely to be correlated with these two other factors.

Tables 4 and 5 intend to test hypothesis on VC firms’ project selection skills. Table 4 estimates a probit regression on VC firms that join an existing syndicate only after the $510(\mathrm{k})$ approval and the regression is at the company level. Our dependent variable is a binary choice of 1 when the VC firm joins a syndicate only after approval and zero otherwise. Our results suggest that when new VC firms are invited only after the approval, their investee companies are less likely to make it to IPO. The coefficient on IPO dummy is at the company level and is negative and significant at $10 \%$ level. This is consistent with Hypothesis H2 suggesting that the VC firms that could identify good projects will not have the incentive to invite new VC firms into the syndicate to share potential high expected returns. VC firms that are invited only after the $510(\mathrm{k})$ are invited for reasons other than providing second opinions on a promising venture.

Overall, our results also suggest that VC firms that join the syndicate only after approval are younger firms that the incumbent VCs would not compete with. This result is consistent with Casamatta and Haritchabalet (2007) who argue that competition among VC firms is a factor in syndicate formation. Existing VC firms tend to invite younger VC firms after certification is completed and they are less likely to invite new VCs if the project has a high chance of IPO exit.

We further explore Hypothesis $\mathrm{H} 2$ in Table 5. These regressions are estimated at the company level and dependent variables take the value of 1 when the VC firms successfully take the company public. The base case in all models is the case when the company receives its $510(\mathrm{k})$ approval during the investment period. VC fund invests 
before 510(k) approval is a dummy variable and takes the value of 1 when syndicates make all their rounds of investments prior to the approval. VC fund invests after $510(\mathrm{k})$ approval is a dummy variable that equals 1 when syndicates invest only after the approval. We find that VC fund invests before 510(k) approval is a significant factor for estimating the probability of the venture backed company going public. This confirms our Hypothesis H2 that VC firms who form syndicates without the 510(k) approval and continues to invest without any approval during the investment period are those who are able to identify a high quality investment and eventually benefit from it through a successful exit. Our findings in Table 5 echo the results in Table 4 that VC firms with project selection skills invest into ventures and companies secure all funding prior to 510(k) approval. These companies are likely to make it to IPO.

Table 6 presents the regression results for the models that estimate the probability of companies to receive funding only before and only after certification. We aim to test hypotheses $\mathrm{H} 2$ and $\mathrm{H} 3$ with these models. According to the results in column 1, companies that receive funding only after certification receive less number of rounds from a smaller group of VC firms and these companies are older. Having a single lead VC firm is less likely for such companies as well. For companies that receive funding only after 510(k) approval, their lead VCs tend to be less experienced and therefore these VCs may be in need external for second opinion to validate the value of the company. One way to do this would be working with older and more established companies which already have their 510(k) certification and the results support that argument. Otherwise, companies can choose to have more than one lead VC firm for external certification and our results support that argument as well. However, these companies are less likely to 
eventually make it to IPO. Overall, results suggest that inexperienced lead VC firms tend to co-invest in less risky projects with lower future expected returns.

All funding after certification is also associated with fewer VC firms invested in the start-up company. This result is consistent with the diversification hypothesis because 510k approval does eliminate some amount of the uncertainty about the project and so the need for diversification to lower the risk of the investment is less. We explore more of diversification hypothesis in Table 7.

According to the results in column 2, a company that receives funding only before certification is relatively younger and is less likely to have a single lead VC firm. Lead VC firms for this group of companies tend to be more experienced. These companies are more likely to eventually make it to IPO suggesting that experienced VC firms have the ability to select good investments even before external certification. Given the evidence, more experienced lead VC firms tend to co-invest more in smaller, less established companies that do not have 510k certifications in place but are more likely to make it to IPO. Overall, results suggest that experienced lead VC firms tend to co-invest in more risky projects that eventually have higher returns. This is also consistent with the second opinion hypothesis since there tends to be more than one lead investor.

Our main goal in Table 6 is to test second opinion hypothesis based on VC experience. For that, we take two proxies of $\mathrm{VC}$ experience from the literature. In columns 1 and 2, we create VC experience based on total investments (\$ million) made by VC firm prior to the investment year. In columns 3 and 4, we proxy single lead VC experience by VC age. Results are consistent with two ways of estimating experience. We find that more experienced VCs are associated with all funding before certification 
and less experienced VCs are more likely to associate with all funding after certification. This finding suggests that more experienced VCs rely second opinion in a lesser degree and are comfortable making investments without the external certification. On the other hand, VCs that invest in companies that receive all funding after certification are less experienced suggesting the need of external certification as second opinion on the project. Table 6 findings also reinforce the supports for hypothesis of VC project selection abilities. Companies that receive all funding before certification are associated with higher likelihood of eventual IPO which indicates VCs project selection abilities.

Results in Table 6 suggest that the experience of the lead VC firm is the determining factor in the type of investment that the syndicate is willing to take on and the size of the syndicate also seems to be a function of the type of investment. We further want to examine the relation of the investment risk and syndicate formation behavior by interacting the type of investment with the experience of the lead VC firm in Table 7.

Dependent variable in models of Table 7 is the natural logarithm of the number of investors in the company. Results in column 1 suggest that number of firms in the syndicate is positively related with the number of rounds company receives, the total amount of investment in the company, and the age of the lead VC firm and is negatively related with the age of the company, with the availability of a single lead investor. Companies that have funding before and after certification both have significantly fewer VC firms in the syndicate compared to those that receive certification during funding period. All of these results are consistent with our expectations. 
The results in Table 7 column 2 suggest that for companies that receive funding before certification, as the age of the lead VC firm decreases, the number of VC firms in the syndicate increases. This result further support our conclusion in Table 6 on second opinion hypothesis because controlling for the level of uncertainty in the investment (need for diversification), we observe a significant relation between lead VC firm age and the syndicate size. Under high uncertainty the inexperience of the lead VC firm is compensated with having more investors in the syndicate which supports the second opinion hypothesis.

On the other hand, in Table 7 column 3 results suggest that in less risky projects, as the lead VC firm experience goes down so does the number of VC firms within the syndicate. This means that under low uncertainty, motivation for syndication is driven for reasons other than second opinion. This makes sense since second opinion hypothesis applies to situations in which there is high uncertainty and it is driven by the investors need to certify valuation. When valuation is more certain, syndication might be driven for capital needs and this argument is consistent with our prior results. Companies that receive funding after certification tend to be larger companies with greater capital needs but less potential for high future returns. These findings support our fourth hypothesis on diversification as VC firms invite others to syndicate to avoid high concentration of investment in contain ventures. Experienced lead VC firms might choose to fund such companies with a larger syndicate and tie up less capital in such investments.

\section{Conclusion}


One of the major challenges in venture capital studies is that companies are mostly opaque during the investment period. Usually, these companies are not publicly traded during investment so there is very little information available on the status of these investments to evaluate the prospects of the company. Yet, the relation between the investment behavior of VC firms and investment uncertainty is an important question to understand the decision making criteria of VC firms in general. In the medical device industry, FDA 510(k) approval serves as a source of external validation/certification of quality and helps resolve some of the investment uncertainty for VC firms.

Our paper takes this unique dataset and explores the process and rationale for syndication. Investment round level results shows that $510(\mathrm{k})$ approval does indeed help start-up companies relieve some of the uncertainty about their potential for success. Venture backed companies in our sample are able to draw more dollar funding in the round following certification and more VC firms choose to participate in the following round. However, we do not see any significant increase in the post round company valuation following certification. These results overall suggest that $510(\mathrm{k})$ certification does have a significant effect on the venture-backed company since it allows the company to have greater flow of funds from a greater number of VC investors but the positive effect is not translated to higher company valuation.

Our results further suggest that promising ventures manage to secure financing, or in other words, VC firms are capable in picking valuable investments, without external certification. Investments that secure all of their financing before $510(\mathrm{k})$ approval tend to have higher likelihood of IPO. These companies that receive all funding before certification are also relatively younger and receive significantly fewer dollar investments. 
They are also less likely to be backed by a single lead VC firm. The prior suggests that even though VC firms could be successful in identifying these promising investments early on, VC firms may still need a "second-opinion" to validate the valuation of such ventures. On the other hand, more risky and less promising companies are more likely to use 510(k) certification to signal quality and invite new investors to join the syndicate.

Companies that receive funding after certification are older companies that receive fewer numbers of rounds and a smaller number of VC firms participate in the investment. They are also less likely to eventually make it to IPO. Investment in these companies is less risky due to uncertainty resolution by the external FDA approval, but the potential return on investment is also lower.

Our paper further investigates second opinion and diversification hypotheses. Results show that companies that receive all funding before certification are more likely to associate with experienced/older VCs and companies that receive all funding after are more likely to associate with younger/inexperienced VCs. Younger VCs are in more need for second opinion so tend to invest in companies that have received external certification. Lastly, this paper also finds that in companies that receive all funding after approval, older VCs invite more investors to share investment risk and diversify. This confirms our hypothesis on diversification.

Our sample is limited only to successful FDA 510(K) approvals. Due to unavailability of data on unsuccessful 510(K) applications, we cannot use the failed investment sample as a control. Therefore one side of the uncertainty coin remains unexplained. Future studies that can include syndication dynamics around unsuccessful 
external certification or negative external input events can address some of the issues left untouched and beyond the scope of our study. 


\section{References}

Admati, Anat R., Paul Pfleiderer, 1994, Robust Financial Contracting and the Role of Venture Capitalists, Journal of Finance, 49, 371-402.

Ball, Eric, Hsin-Hui Chiu, and Richard Smith, 2011, Can VCs Time the Market? An Analysis of Exit Choice for Venture-Backed Firms, Review of Financial Studies, Forthcoming

Barry, Christopher, Chris Muscarella, John Peavy, and Michael Vetsuypens, 1990, The role of venture capital in the creation of public companies: Evidence from the going-public process, Journal of Financial Economics 27, 447-472.

Brander, James a., Raphael Amit, and Werner Antweiler, 2002, Venture Capital Syndication: Improved Venture Selection vs. Value-Added Hypothesis, Journal of Economics and Management Strategy 11, 423-452

Casamatta, Catherine, and Carole Haritchabalet, 2007, Experience, Screening and Syndication in Venture Capital Investments, Journal of Financial Intermediation 16, 368-398

Cestone, G., J. Lerner, and L. White. “The Design of Syndicates in Venture Capital.” Working paper, Harvard University and University of Salerno, 2006.

Chemmanur, Thomas J., and Xuan Tian, 2009, Peer Monitoring and Venture Capital Expertise: Theory and Evidence on Syndicate Formation and the Dynamics of VC Interactions, Working Paper

Cummnig, Douglas, Grant Fleming, and Armin Schwienbacher, 2005, Liquidity Risk and Venture Capital Finance, Financial Management 34, 77-105

Fried, Vance H. and Robert D. Hisrich, 1994, Toward a Model of Venture Capital Investment Decision Making, Financial Management 23, 28-37

Gompers, Paul A., 1995, Optimal Investment, Monitoring and the Staging of Venture Capital, Journal of Finance 50, 1461-1489

Gompers, Paul A., 1996, Grandstanding in the Venture Capital Industry, Journal of Financial Economics 42, 133-156

Hsu, David H., 2004, What Do Entrepreneurs Pay for Venture Capital Affiliation? Journal of Finance 59, 1805-1844

Lerner, Josh, 1994a, The Syndication of Venture Capital Investments, Financial Management 23, 16-27 
Lerner, Josh, 1994b, Venture Capitalists and the Decision to Go Public, Journal of Financial Economics 35, 293-316

Lerner, Josh, 1995, Venture capitalists and the oversight of private firms, Journal of Finance 50, 301-18.

Lockett, A., and M. Wright., 1999, The Syndication of Private Equity: Evidence from the UK. Venture Capital, Vol. 1, 303-324

Lockett, A., and M. Wright, 2001, The Syndication of Venture Capital Investments. Omega, Vol. 29, 375-390.

Megginson, William L., and Kathleen H. Weiss, 1991, Venture capitalist certification in initial public offerings, Journal of Finance 46, 879-903.

Sorensen, Morten, 2007, How Smart is Smart Money? A Two-Sided Matching Model of Venture Capital, Journal of Finance 62, 2725-2762

Tian, Xuan, 2011, The causes and consequences of venture capital stage financing Journal of Financial Economics, in press, corrected proof. 
Figure 1

Funding Timeline

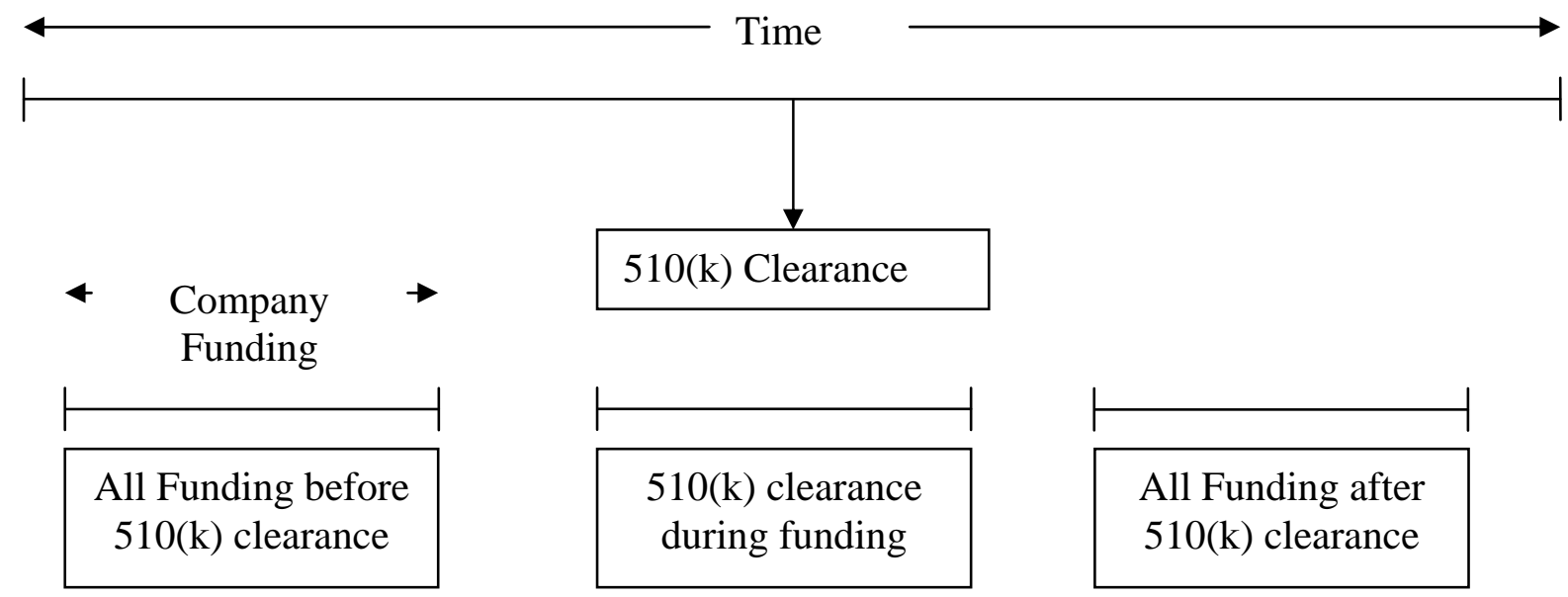


Table 1

Summary statistics for control variables

Panel A presents the summary statistics of our control variables at the company level. Panel B presents descriptive statistics of our control variables at the VC firm level. Panel C presents descriptive statistics of our control variables at the round level. Every control variable is grouped into three categories depending on whether the company received its $510(\mathrm{k})$ approval before, after or during the funding period. Data consist of venture-backed companies identified from SDC Platinum Venture Xpert database from 1980 to 2007 that received 510(k) approval. In Panel A, descriptive statistics are reported for age of company, total amount invested in company, number of firms invested in company, number of rounds company received, time from approval to initial funding calculated as the number of days from the day of approval to initial VC funding and time from approval to IPO calculated as the number of days from the day of approval to IPO date.

\section{Panel A}

\begin{tabular}{|c|c|c|c|c|c|c|}
\hline & & Mean & Median & Min & Max & $\mathbf{N}$ \\
\hline \multirow{4}{*}{$\begin{array}{l}\text { Age of company } \\
\text { at first round }\end{array}$} & All funding before 510(k) & 2.75 & 1 & 0 & 24 & 323 \\
\hline & All funding after $510(\mathrm{k})$ & 6.79 & 4 & 0 & 24 & 282 \\
\hline & 510(k) during funding & 1.78 & 1 & 0 & 24 & 217 \\
\hline & Total & 3.88 & 2 & 0 & 24 & 822 \\
\hline \multirow{4}{*}{$\begin{array}{l}\text { Total amount } \\
\text { invested in } \\
\text { company }\end{array}$} & All funding before 510(k) & 4450.16 & 1405 & 1 & 344150 & 349 \\
\hline & All funding after 510(k) & 5396.41 & 2000 & 5 & 87500 & 287 \\
\hline & 510(k) during funding & 5216.49 & 2581 & 42 & 85678 & 224 \\
\hline & Total & 4965.55 & 1990.5 & 1 & 344150 & 860 \\
\hline \multirow{5}{*}{$\begin{array}{l}\text { Number of } \\
\text { firms invested in } \\
\text { company }\end{array}$} & & & & & & \\
\hline & All funding before 510(k) & 3.93 & 3 & 1 & 21 & 388 \\
\hline & All funding after 510(k) & 2.72 & 2 & 1 & 21 & 352 \\
\hline & 510(k) during funding & 5.33 & 5 & 1 & 25 & 234 \\
\hline & Total & 3.83 & 3 & 1 & 25 & 974 \\
\hline \multirow{4}{*}{$\begin{array}{l}\text { Number of } \\
\text { rounds company } \\
\text { received }\end{array}$} & All funding before $510(\mathrm{k})$ & 5.24 & 4 & 1 & 21 & 388 \\
\hline & All funding after $510(\mathrm{k})$ & 3.43 & 2 & 1 & 19 & 352 \\
\hline & 510(k) during funding & 8.03 & 7 & 1 & 32 & 234 \\
\hline & Total & 5.26 & 4 & 1 & 32 & 974 \\
\hline \multirow{4}{*}{$\begin{array}{l}\text { Time from } \\
\text { approval to } \\
\text { initial } \\
\text { investment }\end{array}$} & All funding before 510(k) & 2260.39 & 1662. & 17 & 16546 & 387 \\
\hline & All funding after $510(\mathrm{k})$ & -2118.19 & -1297 & -11069 & 5433 & 352 \\
\hline & 510(k) during funding & 862.16 & 580 & 11 & 10282 & 234 \\
\hline & Total & 340.1 & 444 & -11069 & 16546 & 973 \\
\hline \multirow{4}{*}{$\begin{array}{l}\text { Time of } \\
\text { approval to IPO }\end{array}$} & All funding before $510(\mathrm{k})$ & 1980.8 & 1579 & -2800 & 36003 & 158 \\
\hline & All funding after 510(k) & 495.55 & 856 & -18113 & 9272 & 75 \\
\hline & 510(k) during funding & 2151.4 & 1770 & -1808 & 13732 & 58 \\
\hline & Total & 1632 & 1449 & -18113 & 36003 & 291 \\
\hline
\end{tabular}




\section{Panel B}

In Panel B, descriptive statistics are reported for Young VC firm dummy that takes a value of 1 if the VC firm is less than 6 years old, young lead VC firm dummy that takes a value of 1 if there is a young VC firm among the VC firms that invested in the company in the first round, standard deviation of VC firm age in syndicate is the standard deviation of the VC firms within the syndicate, age of firm at firm investment is the age of the firm when the firm invests in the company for the first time and the total amount firm invested in the company is the total dollar amount of the investment that the VC firm undertakes during the life of the fund.

\begin{tabular}{|c|c|c|c|c|c|c|}
\hline & & Mean & Median & Min & Max & $\mathbf{N}$ \\
\hline \multirow{4}{*}{$\begin{array}{l}\text { Young VC firm } \\
\text { dummy }\end{array}$} & All funding before 510(k) & 0.40 & 0 & 0 & 1 & 2550 \\
\hline & All funding after $510(\mathrm{k})$ & 0.40 & 0 & 0 & 1 & 444 \\
\hline & 510(k) during funding & 0.35 & 0 & 0 & 1 & 1039 \\
\hline & Total & 0.37 & 0 & 0 & 1 & 2033 \\
\hline \multirow{4}{*}{$\begin{array}{l}\text { Young lead VC firm } \\
\text { dummy }\end{array}$} & All funding before 510(k) & 0.22 & 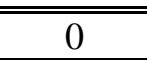 & 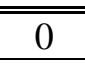 & 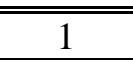 & 550 \\
\hline & All funding after $510(\mathrm{k})$ & 0.20 & 0 & 0 & 1 & 444 \\
\hline & 510(k) during funding & 0.11 & 0 & 0 & 1 & 1039 \\
\hline & Total & 0.16 & 0 & 0 & 1 & 2033 \\
\hline \multirow{4}{*}{$\begin{array}{l}\text { Standard deviation of } \\
\text { VC firm age in } \\
\text { syndicate }\end{array}$} & "All funding before 510(k) & 8.24 & 8 & 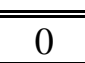 & 20 & 514 \\
\hline & All funding after $510(\mathrm{k})$ & 10.20 & 10 & 0 & 59 & 394 \\
\hline & 510(k) during funding & 9.47 & 9 & 1 & 23 & 1039 \\
\hline & Total & 9.30 & 9 & 0 & 59 & 1947 \\
\hline \multirow{4}{*}{$\begin{array}{l}\text { Age of firm at first } \\
\text { investment }\end{array}$} & "All funding before 510(k) & 13.99 & 10 & 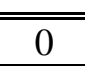 & 46 & 550 \\
\hline & All funding after $510(\mathrm{k})$ & 15.35 & 9 & 0 & 46 & 444 \\
\hline & 510(k) during funding & 14.51 & 11 & 0 & 46 & 1039 \\
\hline & Total & 14.55 & 10 & 0 & 46 & 2033 \\
\hline \multirow{4}{*}{$\begin{array}{l}\text { Total amount firm } \\
\text { invested in company }\end{array}$} & All funding before 510(k) & 3482.39 & 1507 & 12 & 107600 & 527 \\
\hline & All funding after $510(\mathrm{k})$ & 3873.75 & 2009 & 5 & 38000 & 392 \\
\hline & $510(\mathrm{k})$ during funding & 3881.04 & 2339 & 1 & 86527 & 1010 \\
\hline & Total & 3770.65 & 2017 & 1 & 107600 & 1929 \\
\hline
\end{tabular}




\section{Panel C}

In Panel C, descriptive statistics are reported for days between rounds which is the number of days that elapses between consecutive rounds, number of investors each round that represents the total number of VC firms investing in a given period, amount invested in each round which represents the total dollar investment in a given round and the disclosed post round valuation which is the reported valuation of the company after a given round.

\begin{tabular}{|c|c|c|c|c|c|c|}
\hline & & Mean & Median & Min & Max & $\mathbf{N}$ \\
\hline \multirow{4}{*}{$\begin{array}{l}\text { Days between } \\
\text { rounds }\end{array}$} & All funding before 510(k) & 468.10 & 325 & 0 & 10318 & 666 \\
\hline & All funding after 510(k) & 509.74 & 320 & 0 & 5367 & 368 \\
\hline & 510(k) during funding & 509.99 & 365 & 4 & 8362 & 698 \\
\hline & Total & 493.83 & 335 & 0 & 10318 & 1732 \\
\hline \multirow{4}{*}{$\begin{array}{l}\text { Number of } \\
\text { investors } \\
\text { each round }\end{array}$} & All funding before 510(k) & 5.11 & 5 & 1 & 18 & 3093 \\
\hline & All funding after 510(k) & 3.94 & 3 & 1 & 13 & 1654 \\
\hline & 510(k) during funding & 6.19 & 5 & 1 & 25 & 3268 \\
\hline & Total & 5.31 & 4 & 1 & 25 & 8015 \\
\hline \multirow{4}{*}{$\begin{array}{l}\text { Amount } \\
\text { invested in } \\
\text { each round }\end{array}$} & All funding before 510(k) & $7,023.00$ & 3,250 & 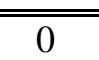 & 89000 & 3899 \\
\hline & All funding after $510(\mathrm{k})$ & $7,502.89$ & 3,428 & 0 & 87500 & 2024 \\
\hline & 510(k) during funding & $8,415.49$ & 5,750 & 0 & 71325 & 4019 \\
\hline & Total & $7,683.60$ & 4,200 & 0 & 89000 & 9942 \\
\hline \multirow{4}{*}{$\begin{array}{l}\text { Disclosed } \\
\text { post round } \\
\text { valuation }\end{array}$} & All funding before $510(\mathrm{k})$ & 37875 & 22419.5 & 625 & 273000 & 306 \\
\hline & All funding after $510(\mathrm{k})$ & 39175.3 & 23200 & 1000 & 168750 & 149 \\
\hline & 510(k) during funding & 34017.9 & 22274 & 287 & 274410 & 396 \\
\hline & Total & 36307.9 & 22800 & 287 & 274410 & 851 \\
\hline
\end{tabular}


Table 2

Univariate statistics for some control variables

Table provides the univariate tests for select variables throughout the sample before and after the 510(k) approval.

Test for differences in means

\begin{tabular}{|l|c|c|c|c|}
\hline \hline & $\begin{array}{c}\text { Mean (Before } \\
\mathbf{5 1 0 ( k ) )}\end{array}$ & $\begin{array}{c}\text { Mean (After } \\
\mathbf{5 1 0 ( k ) )}\end{array}$ & t-value & $\operatorname{Pr}(|\mathbf{T}|>|\mathbf{t}|)$ \\
\hline Age of firm at first investment & 14.54 & 14.58 & $\mathbf{- 0 . 0 7}$ & 0.94 \\
\hline Days between rounds & 437.28 & 534.94 & $\mathbf{- 2 . 8 4}$ & 0.01 \\
\hline Number of investors each round & 5.18 & 5.41 & $\mathbf{- 2 . 7 6}$ & 0.01 \\
\hline Amount invested in each round & 5939.61 & 9296.58 & $\mathbf{- 1 7 . 7 5}$ & 0.00 \\
\hline Disclosed post round valuation & 34009.8 & 41927.39 & $\mathbf{- 2 . 6 8}$ & 0.01 \\
\hline
\end{tabular}


Table 3

Regressions for the effect of $\mathbf{5 1 0 ( k )}$

All variables have been winsorized at the $1 \%$ and $99 \%$ levels. Table 1 presents the summary statistics of the variables used in the model. All estimations include industry effects, year and round effects. We report pvalues in parentheses below the parameter estimates; p-values are calculated using White's (1980) heteroskedasticity consistent standard errors.

\section{Panel A}

\begin{tabular}{|l|c|c|}
\hline & $\begin{array}{c}\text { Log(Amount } \\
\text { invested in } \\
\text { round) }\end{array}$ & $\begin{array}{c}\text { \% change in } \\
\text { number of } \\
\text { investors from } \\
\text { previous round }\end{array}$ \\
\hline \hline Dummy for 510(k) approval since prior round & $0.528^{* * *}$ & $6.246^{*}$ \\
\hline \% change in number of VC firms & $(0.001)$ & $(0.095)$ \\
\hline & $0.0178^{* * *}$ & \\
\hline Acquired dummy & $(0.000)$ & \\
\hline & 0.0618 & -1.775 \\
\hline Log(Age of Company) & $(0.586)$ & $(0.520)$ \\
\hline & $-0.240^{* * *}$ & -1.323 \\
\hline Log(Age of Firm) & $(0.000)$ & $(0.578)$ \\
\hline & 0.0370 & 0.441 \\
\hline IPO dummy & $(0.548)$ & $(0.718)$ \\
\hline & $0.621^{* * *}$ & $-4.524^{* * *}$ \\
\hline Log (Total amount invested in company) & $(0.000)$ & $(0.001)$ \\
\hline & $1.048^{* * *}$ & $-3.029 * *$ \\
\hline Log(Amount invested in round) & $(0.000)$ & $(0.036)$ \\
\hline & & $4.770 * * *$ \\
\hline Constant & & $(0.000)$ \\
\hline & $-4.555^{* * *}$ & $57.88^{* *}$ \\
\hline Year and industry dummies & $(0.001)$ & $(0.023)$ \\
\hline Round number dummy & Yes & Yes \\
\hline Observations & 1723 & Yes \\
\hline R-squared & 0.427 & 0.153 \\
\hline & & \\
\hline & & 1723 \\
\hline & & \\
\hline & & \\
\hline & & \\
\hline & & \\
\hline
\end{tabular}




\section{Panel B}

\begin{tabular}{|l|c|}
\hline & $\begin{array}{c}\text { \% change of post round } \\
\text { valuation relative to prior } \\
\text { round }\end{array}$ \\
\hline \hline Dummy for 510(k) approval since prior round & -9.534 \\
\hline \% change of dollar investment & $(0.481)$ \\
\hline \% change in number of VC firms & $0.289 * * *$ \\
\hline & $(0.000)$ \\
\hline Acquired dummy & $0.340 *$ \\
\hline & $(0.086)$ \\
\hline Log(Age of Company) & -5.883 \\
\hline & $(0.735)$ \\
\hline Log(Age of Firm) & -23.65 \\
\hline & $(0.156)$ \\
\hline IPO dummy & -2.293 \\
\hline & $(0.785)$ \\
\hline Log (Total amount invested in company) & 11.52 \\
\hline & $(0.492)$ \\
\hline Constant & 5.349 \\
\hline & $(0.627)$ \\
\hline Year and industry dummies & -116.7 \\
\hline Round number dummy & $(0.399)$ \\
\hline Observations & Yes \\
\hline R-squared & Yes \\
\hline
\end{tabular}


Table 4

Probit regression for the probability of a VC firm to join the funding only after $510(\mathrm{k})$

All variables have been winsorized at the $1 \%$ and $99 \%$ levels. Table 1 presents the summary statistics of the variables used in the model. All estimations include industry effects and year effects. We report p-values in parentheses below the parameter estimates; p-values are calculated using White's (1980) heteroskedasticity consistent standard errors.

\begin{tabular}{|l|c|}
\hline & $\begin{array}{c}\text { VC Firm joins existing } \\
\text { syndicate only after 510(k) } \\
\text { approval }\end{array}$ \\
\hline \hline Log(Age of VC firm) & $-0.094^{* * *}$ \\
\hline IPO dummy & $(0.000)$ \\
\hline & $-0.087 *$ \\
\hline Log (Total amount invested in company) & $(0.092)$ \\
\hline & -0.027 \\
\hline Log(Number of rounds company received) & $(0.454)$ \\
\hline & $-0.223^{* * *}$ \\
\hline Log(Number of firms invested in company) & $(0.000)$ \\
\hline & $0.329 * * *$ \\
\hline Log(Age of company at first round) & $(0.000)$ \\
\hline & $-0.156 * * *$ \\
\hline Standard deviation of VC firms in syndicate & $(0.000)$ \\
\hline & -0.005 \\
\hline Constant & $(0.372)$ \\
\hline & -0.934 \\
\hline Year and industry dummies & $(0.330)$ \\
\hline Observations & Yes \\
\hline R-squared & 7446 \\
\hline & 0.081 \\
\hline
\end{tabular}


Table 5

Probit regression for the probability of IPO

All variables have been winsorized at the $1 \%$ and $99 \%$ levels. Table 1 presents the summary statistics of the variables used in the model. All estimations include industry effects and year effects. We report p-values in parentheses below the parameter estimates; p-values are calculated using White's (1980) heteroskedasticity consistent standard errors.

\begin{tabular}{|l|c|c|}
\hline & $\begin{array}{c}\text { IPO } \\
\text { dummy }\end{array}$ & $\begin{array}{c}\text { IPO } \\
\text { dummy }\end{array}$ \\
\hline \hline VC fund invests before 510(k) approval & & \\
\hline VC fund invests after 510(k) approval & $0.450^{* * *}$ & \\
\hline & $(0.003)$ & \\
\hline Initial investment made without 510(k) approval & -0.00366 & \\
\hline & $(0.985)$ & \\
\hline Log (Total amount invested in company) & & $0.285^{*}$ \\
\hline & $0.533^{* * *}$ & $0.536^{* * *}$ \\
\hline Log(Number of rounds company received) & $(0.000)$ & $(0.000)$ \\
\hline & 0.121 & 0.0863 \\
\hline Log(Number of firms invested in company) & $(0.322)$ & $(0.476)$ \\
\hline & -0.192 & -0.215 \\
\hline Log(Age of company at first round) & $(0.182)$ & $(0.129)$ \\
\hline & 0.0744 & 0.0784 \\
\hline Standard deviation of VC firms in syndicate & $(0.356)$ & $(0.323)$ \\
\hline & $0.0232^{*}$ & $0.0247^{* *}$ \\
\hline Constant & $(0.065)$ & $(0.046)$ \\
\hline & $-3.265^{* *}$ & $-5.253^{* * *}$ \\
\hline Year and industry dummies & $(0.017)$ & $(0.002)$ \\
\hline Observations & Yes & Yes \\
\hline R-squared & 636 & 636 \\
\hline
\end{tabular}


Table 6

Characteristics of companies that receive funding only before or only after $510(\mathrm{k})$ certification

All variables have been winsorized at the $1 \%$ and $99 \%$ levels. Table 1 presents the summary statistics of the variables used in the model. All estimations include industry and year effects. We report p-values in parentheses below the parameter estimates; p-values are calculated using White's (1980) heteroskedasticity consistent standard errors.

\begin{tabular}{|c|c|c|c|c|}
\hline & $\begin{array}{l}\text { All funding } \\
\text { after } \\
\text { certification }\end{array}$ & $\begin{array}{l}\text { All funding } \\
\text { before } \\
\text { certification }\end{array}$ & $\begin{array}{l}\text { All funding } \\
\text { after } \\
\text { certification }\end{array}$ & $\begin{array}{c}\text { All funding } \\
\text { before } \\
\text { certification }\end{array}$ \\
\hline \multirow[t]{2}{*}{ IPO dummy } & -0.209 & $0.512^{* * *}$ & -0.188 & $0.494 * * *$ \\
\hline & $(0.165)$ & $(0.000)$ & $(0.207)$ & $(0.000)$ \\
\hline \multirow[t]{2}{*}{ Acquired dummy } & 0.129 & -0.0229 & 0.116 & 0.0168 \\
\hline & $(0.444)$ & $(0.888)$ & $(0.496)$ & $(0.917)$ \\
\hline \multirow[t]{2}{*}{$\begin{array}{l}\text { Log (Total amount invested in } \\
\text { company) }\end{array}$} & -0.0227 & -0.0790 & 0.00589 & -0.0660 \\
\hline & $(0.759)$ & $(0.265)$ & $(0.931)$ & $(0.316)$ \\
\hline \multirow[t]{2}{*}{$\begin{array}{l}\text { Log(Number of rounds company } \\
\text { received) }\end{array}$} & -0.157 & -0.0473 & -0.131 & -0.0532 \\
\hline & $(0.196)$ & $(0.686)$ & $(0.274)$ & $(0.651)$ \\
\hline \multirow[t]{2}{*}{$\begin{array}{l}\text { Log(Number of firms invested in } \\
\text { company) }\end{array}$} & $-0.320 * *$ & -0.177 & $-0.390 * * *$ & -0.195 \\
\hline & $(0.025)$ & $(0.209)$ & $(0.006)$ & $(0.157)$ \\
\hline \multirow[t]{2}{*}{ Single lead investor dummy } & $-0.273 *$ & $-0.334 * *$ & $-0.366 * *$ & $-0.278 * *$ \\
\hline & $(0.064)$ & $(0.019)$ & $(0.014)$ & $(0.047)$ \\
\hline \multirow[t]{2}{*}{ Log(Age of company at first round) } & $0.552 * * *$ & $-0.266 * * *$ & $0.510 * * *$ & $-0.247 * * *$ \\
\hline & $(0.000)$ & $(0.000)$ & $(0.000)$ & $(0.000)$ \\
\hline \multirow[t]{2}{*}{ Buyout company dummy } & 0.194 & -0.0617 & 0.186 & -0.00708 \\
\hline & $(0.175)$ & $(0.645)$ & $(0.189)$ & $(0.957)$ \\
\hline \multirow[t]{2}{*}{ Age of lead VC firm } & & & $-0.223 * * *$ & $0.192 * * *$ \\
\hline & & & $(0.000)$ & $(0.002)$ \\
\hline \multirow[t]{2}{*}{ Weighted average of VC firm age } & & & 0.0410 & -0.0595 \\
\hline & & & $(0.629)$ & $(0.465)$ \\
\hline \multirow[t]{2}{*}{ Experience of lead VC firm } & $-0.484 *$ & $0.457 *$ & & \\
\hline & $(0.092)$ & $(0.071)$ & & \\
\hline \multirow[t]{2}{*}{ Weighted average of VC experience } & 1.404 & -0.475 & & \\
\hline & $(0.237)$ & $(0.666)$ & & \\
\hline \multirow[t]{2}{*}{ Constant } & -2.034 & 1.176 & -4.052 & 0.0152 \\
\hline & $(0.000) * * *$ & $(0.339)$ & $(0.000)^{* * *}$ & $(0.992)$ \\
\hline Year, industry, company dummies & Yes & Yes & Yes & Yes \\
\hline Observations & 659 & 674 & 669 & 684 \\
\hline R-squared & 0.2676 & 0.2778 & 0.1767 & 0.1814 \\
\hline
\end{tabular}




\section{Table 7}

Regressions estimating the level of syndication for a given company

All variables have been winsorized at the $1 \%$ and $99 \%$ levels. Table 1 presents the summary statistics of the variables used in the model. All estimations include industry and year effects. We report p-values in parentheses below the parameter estimates; p-values are calculated using White's (1980) heteroskedasticity consistent standard errors.

\begin{tabular}{|c|c|c|c|}
\hline & $\begin{array}{c}\text { Log(Number } \\
\text { of investors } \\
\text { in company) } \\
\end{array}$ & $\begin{array}{c}\text { Log(Number } \\
\text { of investors } \\
\text { in company) } \\
\end{array}$ & $\begin{array}{l}\text { Log(Number } \\
\text { of investors } \\
\text { in company) } \\
\end{array}$ \\
\hline \multirow[t]{2}{*}{ All funding before certification } & $-0.166^{* * *}$ & 0.0284 & $-0.166^{* * *}$ \\
\hline & $(0.000)$ & $(0.752)$ & $(0.000)$ \\
\hline \multirow[t]{2}{*}{ All funding after certification } & $-0.197 * * *$ & $-0.185 * * *$ & $-0.374 * * *$ \\
\hline & $(0.000)$ & $(0.000)$ & $(0.000)$ \\
\hline \multirow[t]{2}{*}{ Log(Number of rounds company received) } & $0.401 * * *$ & $0.399 * * *$ & $0.404 * * *$ \\
\hline & $(0.000)$ & $(0.000)$ & $(0.000)$ \\
\hline \multirow[t]{2}{*}{ Acquired dummy } & 0.0435 & 0.0387 & 0.0410 \\
\hline & $(0.321)$ & $(0.374)$ & $(0.347)$ \\
\hline \multirow[t]{2}{*}{ IPO dummy } & -0.0236 & -0.0187 & -0.0160 \\
\hline & $(0.586)$ & $(0.666)$ & $(0.713)$ \\
\hline \multirow[t]{2}{*}{ Log(Weighted average of VC firm age) } & 0.0242 & 0.0262 & 0.0242 \\
\hline & $(0.330)$ & $(0.291)$ & $(0.333)$ \\
\hline \multirow[t]{2}{*}{ Log(Age of lead VC firm) } & $0.0351 * *$ & $0.0622 * * *$ & 0.00439 \\
\hline & $(0.048)$ & $(0.002)$ & $(0.835)$ \\
\hline \multirow[t]{2}{*}{ Log(Age of company at first round) } & $-0.0695 * * *$ & $-0.0710^{* * *}$ & $-0.0739 * * *$ \\
\hline & $(0.002)$ & $(0.001)$ & $(0.001)$ \\
\hline \multirow[t]{2}{*}{ Weighted firm investment diversification } & -0.000243 & -0.000387 & -0.000418 \\
\hline & $(0.860)$ & $(0.776)$ & $(0.760)$ \\
\hline \multirow[t]{2}{*}{ Buyout company dummy } & $0.189 * * *$ & $0.190 * * *$ & $0.187 * * *$ \\
\hline & $(0.000)$ & $(0.000)$ & $(0.000)$ \\
\hline \multirow[t]{2}{*}{ Log(Total invested amount in company) } & $0.216 * * *$ & $0.218 * * *$ & $0.215 * * *$ \\
\hline & $(0.000)$ & $(0.000)$ & $(0.000)$ \\
\hline \multirow[t]{2}{*}{ Single lead investor dummy } & $-0.364 * * *$ & $-0.360 * * *$ & $-0.364 * * *$ \\
\hline & $(0.000)$ & $(0.000)$ & $(0.000)$ \\
\hline \multirow[t]{2}{*}{ All funding after certification*Log(Age of lead VC) } & & & $0.0765 * *$ \\
\hline & & & $(0.022)$ \\
\hline \multirow[t]{2}{*}{ All funding before certification*Log(Age of lead VC) } & & $-0.0761 * *$ & \\
\hline & & $(0.017)$ & \\
\hline \multirow[t]{2}{*}{ Constant } & $-1.772 * * *$ & $-1.881 * * *$ & $-1.617 * * *$ \\
\hline & $(0.000)$ & $(0.000)$ & $(0.000)$ \\
\hline Year, industry, company dummies & Yes & Yes & Yes \\
\hline Observations & 712 & 712 & 712 \\
\hline R-squared & 0.768 & 0.770 & 0.770 \\
\hline
\end{tabular}

